Article

\title{
Integrated Nutrient Management Enhances Soil Quality and Crop Productivity in Maize-Based Cropping System
}

\author{
Muhammad Abid ${ }^{1,2}$, Tahira Batool ${ }^{3}$, Ghulam Siddique ${ }^{4}$, Shafaqat Ali ${ }^{5,6, * \mathbb{C}}$, Rana Binyamin ${ }^{7}$, \\ Munazzam Jawad Shahid ${ }^{5}$, Muhammad Rizwan ${ }^{5}{ }^{-0}$, Abdulaziz Abdullah Alsahli ${ }^{8}$ \\ and Mohammed Nasser Alyemeni ${ }^{8}$ \\ 1 Department of Soil Conservation, Narowal 51600, Pakistan; hishamuaf@yahoo.com \\ 2 Key Laboratory of Crop Physiology, Ecology and Production Management, Nanjing Agricultural University, \\ Nanjing 210095, China \\ 3 Department of Botanical Sciences, University of Sargodha, Sargodha 40210, Pakistan; \\ tahirabatool589@gmail.com \\ 4 Directorate General of Agriculture (Field Wing), Lahore 54000, Pakistan; fieldwing@gmail.com \\ 5 Department of Environmental Sciences and Engineering, Government College University, Faisalabad 38000, \\ Pakistan; munazzam01@gmail.com (M.J.S.); mrazi1532@yahoo.com (M.R.) \\ 6 Department of Biological Sciences and Technology, China Medical University, Taichung 40402, Taiwan \\ 7 Sub Campus Burewala, University of Agriculture Faisalabad, Faisalabad 38000, Pakistan; \\ Binyamin1388@gmail.com \\ 8 Department of Botany and Microbiology, College of Science, King Saud University, Riyadh 11451, \\ Saudi Arabia; aalshenaifi@ksu.edu.sa (A.A.A.); mnyemeni@ksu.edu.sa (M.N.A.) \\ * Correspondence: shafaqataligill@yahoo.com or shafaqataligill@gcuf.edu.pk
}

Received: 12 November 2020; Accepted: 30 November 2020; Published: 7 December 2020

check for updates

\begin{abstract}
Soil quality deterioration, especially in intensive cropping systems, has become a serious problem for crop productivity; consequently, strategies for sustainable crop production and soil health are urgently required. Experiments on fields were organized to investigate the impact of organic manures on crop productivity, soil physiochemical properties and soil water availability in a maize-based cropping system. The experiment consisted of five treatments, including organic manures (OM) and inorganic nitrogen, phosphorus and potassium (NPK) fertilizers applied separately and in combinations: NPK $=250-150-125 \mathrm{Kg} / \mathrm{ha}$ (recommended rate), farmyard manure $(\mathrm{FYM})=16 \mathrm{t} / \mathrm{ha}$, poultry manure $(\mathrm{PM})=13 \mathrm{t} / \mathrm{ha}, \mathrm{NPK}+\mathrm{FYM}=150-85-50 \mathrm{Kg} / \mathrm{ha}+8.5 \mathrm{t} / \mathrm{ha}$ and $\mathrm{NPK}+\mathrm{PM}=150-85-50 \mathrm{Kg} / \mathrm{ha}+7.0 \mathrm{t} / \mathrm{ha}$. The results showed that the combination of OM with mineral fertilizers increased crop productivity, fertilizer use efficiency and yield sustainability indices over the treatments amended with sole application of mineral fertilizers and OM. The analysis of undisturbed soil samples during different crop growth stages revealed that the addition of OM decreased the bulk density and increased the pore volume of soil at the beds of 0-20 and $20-40 \mathrm{~cm}$. The application of OM to the soil not only increased saturated hydraulic conductivity of the soil but also improved total available and readily available water contents to the plants, especially when FYM was included at $16 \mathrm{t} \mathrm{ha}^{-1}$. Soil-water retention properties recorded over the entire seven-day monitoring period following irrigation in the OM-amended treatments were consistently higher than the sole mineral NPK application treatments. When testing the soil nutrient status during different crop growth stages, it was noted that by adding OM into the soil not only the status of the organic carbon of soil, extractable $\mathrm{N}$ and $\mathrm{K}$ and available $\mathrm{P}$ contents is increased, but the duration of their availability to the plants are also enhanced. The results of the study show that organic manures addition is of major significance for maintaining soil quality and crop production sustainably, and should be advocated in the nutrient management strategies of intensive water- and nutrient-demanding cropping systems.
\end{abstract}


Keywords: organic manures; soil physiochemical properties; fertilizer use efficiency; soil water contents; maize production

\section{Introduction}

Loss in the fertility of soil has become a primary root reason of less availability of among persons, especially in smallholder farms of the world, and water scarcity further aggravates this problem [1,2]. This trend is becoming more severe due to widely adopted practices of intensive and incessant cropping with poor soil management [3]. The unprecedentedly increasing population and gradually decreasing arable land, plus incessantly depleting soil fertility issues, represent a dire need to improve crop production and sustain the available natural resources by confronting agronomic management efforts $[4,5]$.

Maize (Zea mays L.), due to its high production potential as compared to any other cereal crop, especially under favorable growing conditions, is considered to be one of the most eminent food security crops worldwide [6]. Nitrogen, phosphorus and potassium (named NPK collectively) are the primary nutrients required for plant growth and are applied to soil either through chemical fertilizers or organic manures to fulfill crop nutrient requirements [7,8]. Although increased crop production is attributed to genetic improvements and extensive chemical fertilizer applications, overreliance on synthetic chemical fertilizers has resulted in serious environmental hazards, deteriorated soil properties and decreased maize crop yields over time [9]. Long-term studies have shown that intensive maize-based cropping systems are showing signs of fatigue, proved by stagnating or declining crop productivity and soil quality $[8,10,11]$. The implication of organic manures $(\mathrm{OM})$ in crop production not only improves soil physiochemical properties but also increases crop productivity and is eco-friendly, cheap, readily available and a potential source of nutrients [12]. However, OM cannot overcome the nutritional requirements of crop over the broad zones alone as it contains reduced and imbalanced amounts of nutrients and its application is labor-intensive due to its bulky nature [13]. However, its addition to soil is supportive in reducing the effects of heavy metals and their uptake in crops, depending on their quality and quantity and the level of contaminants present in the soil-plant systems [6].

Due to their limitations, neither inorganic fertilizers nor OM can ensure sustainable crop productivity when applied separately [6,10]; however, an integrated nutrient management system (combined use of inorganic as well as organic fertilizers) could be the best alternate strategy for maintaining and/or restoring the fertility of soil and productivity of crops on a sustainable basis [8]. The synchronization of OM with chemical fertilizers synergizes the efficiency of chemical fertilizers by producing more soil $\mathrm{N}$ and organic carbon, which in turn can reduce the requirements of chemical fertilizers for crop production [12]. Previous research indicated that $\mathrm{N}$ use efficiency was improved as a consequence of $\mathrm{OM}$ application, which in turn reduced the chemical fertilizer requirement of $\mathrm{N}$ by up to $30 \%$ for wheat crop [14]. OM has the potential to increase growth of plant by improving the soil's chemical attributes (nutrient availability, nutrient retention, nutrient cycling), physical properties of soil like bulk density, permeability, porosity, water holding capacity, and soil biological activities $[4,15,16]$.

Soil attributes, such as water holding capacity, bulk density, permeability and contents of organic matter determine soil health and plant growth. When bulk density, the extent of the firmness of soil rises to a significant level, it becomes roots can hardly penetrate the soil, hence the root growth is hindered [17]. Similarly, soil porosity reflects the air or water-filled spaces between the soil particles, whereas water holding capacity is the capability of micropores of soil to hold water for plant [18]. These soil properties can affect the plant-available soil water status and root development that act positively in the uptake of water and nutrients. Organic matter is about five times lighter than mineral soil. It has been reported that an increase in OM from $1 \%$ to $3 \%$ can increase the available water capacity of soil by two [19]. Hathaway-Jenkins (2011) found that infiltration rates of organically 
managed grassland soils were significantly increased compared to conventionally managed grasslands, the amount of water held in soil being increased by $23 \%$ and the predicted runoff reduced by $28 \%$ [20].

However, investigating the optimum dose of integrated nutrient application is required to maintain an adequate supply of nutrients for improved and sustained crop production in a high nutrient-demanding maize cropping system. Pakistan is an importer of chemical fertilizers and maize is it's the 3rd most vital cereal crop after wheat and rice, accounting for more than $10 \%$ of total agricultural production and $15 \%$ of total agricultural employment in Pakistan, $50 \%$ of which is contributed by small land-holding farms [21]. Maize is cultivated on an region of 1.016 million hectares with 3.037 million tons per annum production and $2864 \mathrm{~kg} \mathrm{ha}^{-1}$ average grain yield [21]. Low soil fertility, low and uneven nutrient availability and disturbed soil properties are becoming the main yield-limiting constraints for small landholders with maize crop in Pakistan [10]. On the other hand, the country has a high population of livestock and poultry, so OM is readily available. Under such a scenario, there is a possibility of combined application of nutrient for viable production of crop in cropping arrangements based on maize. Therefore, it is very important to assess the outcome of integrated nutrient application on crop productivity under field conditions in relation to crop growth, of crop and soil properties at a given site. This work was designed to examine the effect of OM on yield growth and the physiochemical properties of soil in maize cropping areas when applied alone or with mineral fertilizers. The results of the study will provide economically attractive evidence to small landholders concerning soil use and management under conditions in which chemical fertilizers are expensive and limitedly available.

\section{Materials and Methods}

\subsection{Depiction of Experimental Location and Crop Husbandry}

A field experiment of two years was conducted at the Agronomic Research Farm, University of Agriculture, Faisalabad $\left(32^{\circ} 16^{\prime}\right.$ N, $119^{\circ} 10^{\prime}$ E) during the 2012 and 2013 growing seasons. This region is categorized as a subtropical and semiarid climate and receives $200-250 \mathrm{~mm}$ rainfall annually, concentrated in the monsoon period (June-August), but the mean pan evaporation value is $1725 \mathrm{~mm}$ which is very high. The mean maximum and minimum temperatures and the rainfall during the experiment period (August-November) for both years were $25-35^{\circ} \mathrm{C}, 15-25{ }^{\circ} \mathrm{C}$ and $182 \mathrm{~mm}$, respectively. The soil of experimental area was sandy clay characterized by sand, silt and clay at 54.0 , 20.5 and $25.4 \%$, respectably. With regard to physiochemical properties, the soil had an organic carbon content of $5.3 \mathrm{~g} \mathrm{~kg}^{-1}$, cation exchange capacity of $17.2 \mathrm{cmol} \mathrm{kg}^{-1}$, water saturation percentage of $35.8 \%$, bulk density of $1.4 \mathrm{~g} \mathrm{~cm}^{-3}, \mathrm{pH}\left(1: 2.5 \mathrm{H}_{2} \mathrm{O}\right)$ of 7.6 , total $\mathrm{N}$ of $0.07 \%$, extractable $\mathrm{K}$ of $180 \mathrm{ppm}$ and available $\mathrm{P}$ of $7.8 \mathrm{ppm}$. A complete block scheme with three repetitions was used and every plot size was $8 \mathrm{~m} \times 4.5 \mathrm{~m}$ with 20 rows in both experiments. An inter-row spacing of $75 \mathrm{~cm}$ was used. A hybrid maize cultivar (Highcorn-8288) which was most widely cultivated in the region was used with a seed rate of $30 \mathrm{~kg} \mathrm{ha}^{-1}$ each year. Thinning was practiced at the three-leaf stage with a plant $\times$ plant distance of $20 \mathrm{~cm}$ to maintain the plant population of approximately 12 plants per $\mathrm{m}^{-2}$ in each experiment.

\subsection{Analysis and Sampling of Organic Manures and Soil}

Samples of soils were assembled from several points of the field $(0-20 \mathrm{~cm}$ depth) each year before the start of the experiment. All collected samples were dried in air, sieved in $2 \mathrm{~mm}$ sieve and analyzed to calculate the physiochemical properties of soil. Particle size of soil was analyzed by using the Bouycous hydro-meter method [22]. Similarly, the organic manures (farmyard manure: FYM, and poultry manure: PM) that were used in this study underwent natural outdoor fermentation for 5-6 months and were obtained from the Veterinary Research Farm of the university. Fermented samples of all manures were randomly collected from their bulks separately, air-dried, cleaned, ground, sieved $(2 \mathrm{~mm})$ and then analyzed for the determination of total dry matter content, $\mathrm{pH}$, total organic $\mathrm{C}$, $\mathrm{N}, \mathrm{P}, \mathrm{K}$, calcium, magnesium and ash contents (Table 1). 
Table 1. Characteristics of organic manures and in-organic fertilizers used in the experiment.

\begin{tabular}{cccccccccc}
\hline Nutrient Source & OC (\%) & C:N & $\begin{array}{c}\mathbf{D M} \\
\mathbf{( \% )}\end{array}$ & $\begin{array}{c}\mathbf{N} \\
\mathbf{( \% )}\end{array}$ & $\begin{array}{c}\mathbf{P} \\
\mathbf{( \% )}\end{array}$ & $\begin{array}{c}\text { K } \\
\mathbf{( \% )}\end{array}$ & $\begin{array}{c}\text { Ca } \\
\mathbf{( \% )}\end{array}$ & Mg (\%) & $\begin{array}{c}\text { Ash } \\
\mathbf{( \% )}\end{array}$ \\
\hline FYM & 18.2 & 14 & 65.3 & 1.3 & 0.41 & 0.73 & 1.9 & 0.8 & 42.5 \\
PM & 24.2 & 16 & 78.5 & 1.75 & 0.65 & 1.07 & 2.2 & 0.6 & 40.1 \\
Urea & - & - & - & 46 & 0 & 0 & - & - & - \\
DAP & - & - & - & 18 & 46 & 0 & - & - & - \\
SOP & - & - & - & 0 & 0 & 50 & - & - & - \\
\hline
\end{tabular}

OC: organic carbon, DM: dry matter content, FYM: farmyard manure, PM: poultry manure, SOP: sulphate of potassium.

\subsection{Treatments Application and Management}

The experiment consisted of five treatments, including usess of organic composts and in-organic fertilizers separately and in combinations, which are given as: NPK $=250-150-125 \mathrm{~kg} \mathrm{ha}^{-1}$ (recommended rate), FYM $=16 \mathrm{tha}^{-1}, \mathrm{PM}=13 \mathrm{tha}^{-1}, \mathrm{NPK}+\mathrm{FYM}=150-85-50 \mathrm{~kg} \mathrm{ha}^{-1}+8.5 \mathrm{tha}^{-1}$ and NPK $+\mathrm{PM}=150-85-50 \mathrm{~kg} \mathrm{ha}^{-1}+7.0 \mathrm{tha}^{-1}$ (Table 2). The OM and mineral phosphorus, potassium and $1 / 3 \mathrm{~N}$ were smeared while sowing seeds. The other two doses of $\mathrm{N}$ were applied as equivalent parts at the time of first irrigation and at the five-leaf stage of the crop, respectively. After the application of $\mathrm{OM}$, they were incorporated into the soil using a double manual rotary hoe in each plot separately. All other agronomic and plant protection operations were kept uniform for all treatments according to local recommendations to avoid the effect of other factors.

Table 2. Description of treatments applied in the study.

\begin{tabular}{cc}
\hline Treatments & Application Rate \\
\hline NPK & $250-150-125 \mathrm{~kg} \mathrm{ha}^{-1}$ \\
FYM & $16 \mathrm{t} \mathrm{ha}^{-1}$ \\
PM & $13 \mathrm{t} \mathrm{ha}^{-1}$ \\
NPK + FYM & $150-85-50 \mathrm{~kg} \mathrm{ha}^{-1}+8.5 \mathrm{tha}^{-1}$ \\
NPK + PM & $150-85-50 \mathrm{~kg} \mathrm{ha}^{-1}+7.0 \mathrm{tha}^{-1}$ \\
\hline
\end{tabular}

FYM: farmyard manure, PM: poultry manure, NPK: nitrogen, phosphorus and potassium.

The amounts of chemical fertilizers and organic manures required for each plot under a specific treatment were calculated by the equation given below:

$$
\text { Amount of nutrient source to be applied }=\frac{\mathrm{R} \times \mathrm{A} \times 100}{10,000 \times \mathrm{C}}
$$

where $\mathrm{R}$ is the recommended rate of fertilizer $(\mathrm{kg} / \mathrm{ha}), \mathrm{A}$ is the area of the plot $\left(\mathrm{m}^{2}\right), \mathrm{C}$ is the concentration of a nutrient element in the source $(\%)$ and 10,000 is the hectare area $\left(\mathrm{m}^{2}\right)$.

\subsection{Analyses and Sampling of Soil}

At the five-leaf (V5) and silking (R1) stages of the crop, six replicated and uninterrupted samples of soil were received from $0-20$ and $20-40 \mathrm{~cm}$ depth for each plot, using a metal ring (with an inner diameter of $4 \mathrm{~cm}$ and a height of $6 \mathrm{~cm}$ ), from the middle of plant rows. The maize developmental stages were identified according to the standard system proposed by Ritchie et al. (1992). The soil bulk density, porosity and permeability of the collected samples were determined. Bulk density of soil was measured from the mass dried in oven $\left(105^{\circ} \mathrm{C}\right)$ and soil samples volume (Blake and Hartage 1986). Soil porosity was calculated from the ratio of the bulk density to soil particle density, concidering a particle density of $2.65 \mathrm{~g} \mathrm{~cm}^{-3}$. Soil permeability was calculated by placing a column of soil under specific conditions and measuring the decrease in water level after $24 \mathrm{~h}$ (Rhoades 1982). 
Soil water-related properties of plots such as saturation water content (SWC), saturated hydraulic conductivity $(K s)$, water holding capacity (WHC) and readily available water content (RAWC) were determined at the R1 stage of the crop everyday starting from the first day for seven days after irrigation (values from plots before starting treatments were assumed as 0 days for all treatments). The SWC of undisturbed soil samples was estimated by saturating them for $24 \mathrm{~h}$ and calculating the amount of water [23] and the Ks was determined using the constant head method [24]. The WHC of soil (w/w) was determined by calculating the difference between saturated and oven-dried $\left(105^{\circ} \mathrm{C}\right)$ soil samples [19]. The soil-water holding at different matric capacities of the treatments was observed using a high speed cold centrifuge (Model CR21G, Hitachi Co., Ltd., Tokyo, Japan), and RAWC of the soil was determined by calculating the differences in soil water holding at matric potentials of -10 and $-100 \mathrm{kPa}$ [25].

The soil samples for the determination of chemical properties with five replications for each treatment were collected at the five-leaf, silking, milking (R3) and physiological maturity (R6) stages of the crop. Organic carbon content of soil was analyzed according to Walkley and Black's method (1947), available N according to Bremner's method (1996), extractable P according to Bray and Kurtz's method (1945) and available K according to Rhoades' method (1996) [26-29]. Soil pH was assessed potentiometrically by using a $\mathrm{pH}$ meter in a solution of soil of ratio 1:2.5.

\subsection{Measurement of Plant Root Length}

Root samples were collected from the soil profiles at V5, R1, R3 and R6 for plant root length determination by using a sharp-edged iron box of $10 \mathrm{~cm}$ length, $5 \mathrm{~cm}$ width and $10 \mathrm{~cm}$ depth. The iron box was pressed into the soil vertically and opened into it, thus yielding soil cores of these dimensions. The sampling depth was determined by the actual growth of crop roots. Each sample was put into a 100-mesh nylon bag, cleaned with tap water and the root length measured with the measuring foot.

\subsection{Measurements of Crop Yield Traits}

In both experiments, the total arid matter and yield of grain traits were calculated by harvesting plants from three randomly identified areas of one $\mathrm{m}^{2}$ with five replications in each plot at physiological maturity. The harvested plants were sun dried and weighed to record the total biomass. The cobs were removed and shelled manually to determination yield of grain and associated components for each treatment. The final grain yield was set to $14 \%$ moisture and yield traits were determined as follows.

\subsection{Harvest Index}

Harvest index (HI) was studied as the ratio between the weight of grain and the total dry weight of the above powdered biomass:

$$
\mathrm{HI}(\%)=\frac{\text { Grain yield }}{\text { Dry weight of above ground biomass }} \times 100
$$

\subsection{Agronomic Efficiency of Fertilizers}

Agronomic efficiency of fertilizers (i.e., increase in grain yield per unit use of NPK) for each treatment was assessed according to Novoa and Loomis (1981).

$$
\mathrm{AE}(\mathrm{kg} \text { grain } / \mathrm{kg} \mathrm{NPK})=\frac{\mathrm{Y}}{\mathrm{FNPK}}
$$

where, AE is the agronomic efficiency, $\mathrm{Y}$ is the yield of the treated plot and FNPK is the sum of nitrogen, phosphorus and potash applied in the treatment. 


\subsection{Yield Sustainability Index}

The yield sustainability index (i.e., the quantitative assessment of the sustainability of a treatment) was calculated using the method given by Singh et al., (1990):

$$
\mathrm{YSI}=\frac{\mathrm{YM}-\mathrm{Sd}}{\mathrm{YMax}}
$$

where YSI is the yield sustainability index, YM is the mean yield, $\mathrm{Sd}$ is the standard deviation and YMax is the maximum yield of the plot under a treatment.

\subsection{Statistical Analysis}

For all parameters, the difference between treatment means was evaluated by one-way analysis of variance (ANOVA) using Duncan's multiple range test at $p=0.05$. Statistical analysis was carried out using the SPSS statistical package (SPSS Inc., Chicago, IL, USA).

\section{Results}

\subsection{Grain Yield and Total Biomass}

The data for grain yield in Table 3 show that application of NPK, either through inorganic fertilizers or in combination with FYM or PM, significantly increased the grain and biological yields of maize. The maximum grain yield was obtained in those treatments where the integrated application of organic and inorganic manures was used. In the 2012 growing seasons, the highest grain yield $\left(8.43 \mathrm{t} \mathrm{ha}^{-1}\right)$ and total biomass $\left(17.6 \mathrm{t} \mathrm{ha}^{-1}\right.$ ) were recorded in the plots where inorganic fertilizers $150-85-50 \mathrm{~kg} \mathrm{ha}^{-1} \mathrm{NPK}$ were applied with $7 \mathrm{tha}^{-1} \mathrm{PM}$. However, more grain yield $\left(9 \mathrm{t} \mathrm{ha}^{-1}\right)$ and total biomass $\left(18.1 \mathrm{t} \mathrm{ha}^{-1}\right)$ were obtained under the same treatment in the 2013 growing season compared to the 2012 growing season. The second highest grain yield was achieved, with a slight difference, by the treatments in which inorganic fertilizers were applied along with FYM, in both years respectively. The highest $\mathrm{HI}(0.47$ and 0.49 ) was also calculated for the treatments where inorganic fertilizers $150-85-50 \mathrm{~kg} \mathrm{ha}^{-1}$ were applied with 7.0 t ha $^{-1}$ PM during 2012 and 2013, respectively, and the second highest was achieved, with a nonsignificant difference, by the treatments in which inorganic fertilizers were applied along with FYM in both years. In brief, grain yield and total biomass were greater in treatments for which organic and inorganic nutrient sources were applied in combination as compared to their sole applications.

Table 3. Effect of organic manures and inorganic fertilizers on crop yield and related traits in maize during the 2012 and 2013 growing seasons.

\begin{tabular}{|c|c|c|c|c|c|}
\hline Treatments & $\begin{array}{c}\text { Grain Yield } \\
\left(t \mathrm{ha}^{-1}\right)\end{array}$ & $\begin{array}{l}\text { Total Biomass } \\
\quad\left(\mathrm{tha}^{-1}\right)\end{array}$ & HI & $\begin{array}{c}\mathrm{AE} \\
\text { (kg Yield/kg NPK) }\end{array}$ & YSI \\
\hline \multicolumn{6}{|c|}{2012} \\
\hline NPK & $7.50 \mathrm{c}$ & $16.71 \mathrm{c}$ & $0.44 \mathrm{~b}$ & $6.6 \mathrm{~cd}$ & $0.71 \mathrm{c}$ \\
\hline FYM & $6.07 \mathrm{e}$ & $14.83 \mathrm{e}$ & $0.40 \mathrm{~d}$ & $5.3 \mathrm{e}$ & $0.67 \mathrm{~d}$ \\
\hline $\mathrm{PM}$ & $7.13 \mathrm{~d}$ & $15.90 \mathrm{~d}$ & $0.43 \mathrm{bc}$ & $6.8 \mathrm{c}$ & $0.72 \mathrm{c}$ \\
\hline NPK + FYM & $8.00 \mathrm{~b}$ & $17.10 \mathrm{~b}$ & $0.46 \mathrm{ab}$ & $8.3 \mathrm{~b}$ & $0.83 \mathrm{~b}$ \\
\hline $\mathrm{NPK}+\mathrm{PM}$ & $8.43 \mathrm{a}$ & $17.60 \mathrm{a}$ & $0.47 \mathrm{a}$ & $10.3 \mathrm{a}$ & $0.87 \mathrm{a}$ \\
\hline \multicolumn{6}{|c|}{2013} \\
\hline NPK & $7.61 \mathrm{c}$ & $16.83 \mathrm{c}$ & $0.46 \mathrm{bc}$ & $6.8 \mathrm{~d}$ & $0.75 \mathrm{c}$ \\
\hline FYM & $6.33 \mathrm{e}$ & $14.85 \mathrm{e}$ & $0.42 \mathrm{~d}$ & $5.5 \mathrm{e}$ & $0.71 \mathrm{~d}$ \\
\hline PM & $7.25 \mathrm{~d}$ & $15.96 \mathrm{~d}$ & $0.44 \mathrm{c}$ & $7.1 \mathrm{c}$ & $0.75 \mathrm{c}$ \\
\hline NPK + FYM & $8.17 \mathrm{~b}$ & $17.24 \mathrm{~b}$ & $0.48 \mathrm{ab}$ & $8.5 \mathrm{~b}$ & $0.84 \mathrm{~b}$ \\
\hline $\mathrm{NPK}+\mathrm{PM}$ & $8.54 \mathrm{a}$ & $17.75 \mathrm{a}$ & $0.49 \mathrm{a}$ & $10.5 \mathrm{a}$ & $0.90 \mathrm{a}$ \\
\hline
\end{tabular}

HI: harvest index, AE: agronomic efficiency, YSI: yield sustainability index. In the Treatments column, NPK $=250-150-125 \mathrm{~kg} \mathrm{ha}^{-1}$ (recommended rate), FYM $=16 \mathrm{tha}^{-1}, \mathrm{PM}=13 \mathrm{tha}^{-1}, \mathrm{NPK}+\mathrm{FYM}=150-85-50 \mathrm{~kg} \mathrm{ha}^{-1}+8.5 \mathrm{tha}^{-1}$ and NPK $+\mathrm{PM}=$ 150-85-50 kg ha ${ }^{-1}+7.0 \mathrm{t} \mathrm{ha}^{-1}$. Different lowercase letters following the data within a column indicate significant differences at $p<0.05$. The data are the means of five replications $(n=5)$. 


\subsection{Agronomic Efficiency and Yield Sustainability Index}

The AE of fertilizers was greater in all plots under the treatments that were amended with organic manures in combination with mineral fertilizers. The highest values of AE (10.52 kg grain $/ \mathrm{kg} \mathrm{NPK})$ were recorded in the 2012 growing season in the plots where inorganic fertilizers $150-85-50 \mathrm{~kg} \mathrm{NPK} \mathrm{ha}^{-1}$ were applied along with $7 \mathrm{tha}^{-1} \mathrm{PM}$. This was followed by the treatments where mineral fertilizers were applied with FYM, which were higher than sole applications. The first growing season (2012) relatively gave lower AE values (10.32 kg grain/kg NPK) than 2013 (10.52 kg grain/kg NPK). Similarly, YSI, which indicates the quantitative assessment of the sustainability of the treatments, was recorded at higher rates overall for the treatments of mineral fertilizers application integrated with OM. The lowest values of YSI were recorded for the plots treated with sole application of OM, which were about 15\% lower than treatments where organic manures were applied in combination with inorganic fertilizers.

\subsection{Effects on Hydrological and Physical Soil Properties}

The physical and hydrological characteristics of untouched soils under each treatment are shown in Figures 1 and 2. The data show that the soil parameters (soil bulk density, porosity and soil permeability) demonstrated a significant relation to OM application. The differences in these traits between the first sampling (V5) and second sampling stages (R1) were not found but they differed at varying soil layers, with lower bulk density and higher porosity and permeability at $0-20 \mathrm{~cm}$ and opposite trends at the $20-40 \mathrm{~cm}$ soil layer. More positive effects of OM application on these traits were observed in the single application of FYM and PM than in the sole application of NPK and its integration with OM. The OM use lessened the bulk density in the 0-20 and 20-40 cm soil layers from 1.67 and $1.82 \mathrm{~g} \mathrm{~cm}^{-3}$ to 1.25 and $1.33 \mathrm{~g} \mathrm{~cm}^{-3}$ under $16 \mathrm{t} \mathrm{FYM} \mathrm{ha}{ }^{-1}$ and to 1.37 and $1.34 \mathrm{~g} \mathrm{~cm}^{-3}$ under $13 \mathrm{t} \mathrm{PM} \mathrm{ha}{ }^{-1}$ treatments, respectively. The soil porosity and soil permeability were generally inversely correlated with soil bulk density. Significant increases in the soil porosity at the $0-20$ and $20-40 \mathrm{~cm}$ soil layers from 48.33 and $37.86 \%$ in control to 59.9 and $47.5 \%$ in $16 \mathrm{t} \mathrm{FYM} \mathrm{ha}^{-1}$ and to 52.5 and $42.1 \%$ under $13 \mathrm{t} \mathrm{PM} \mathrm{ha}^{-1}$ were observed, respectively. Significant increases in the soil permeability from 389 and $371 \mathrm{~cm} \mathrm{day}^{-1}$ in control to 485 and $400 \mathrm{~cm} \mathrm{day}^{-1}$ in $16 \mathrm{t} \mathrm{FYM} \mathrm{ha}{ }^{-1}$ and to 445 and $380 \mathrm{~cm} \mathrm{day}^{-1}$ in $13 \mathrm{t} \mathrm{PM} \mathrm{ha}{ }^{-1}$ were observed at depths of $0-20$ and $20-40 \mathrm{~cm}$, respectively.

Similarly, the positive effects of OM manures on soil hydraulic properties such as Ks, WHC, SWC and RAWC were observed after irrigation and these effects were more pronounced in the treatments amended with sole application of OM and its integration with mineral NPK than in the treatments with sole application of NPK (Figure 2). The Ks ranged from 1.5 to $1.0 \mathrm{~mm} \mathrm{~min}^{-1}$ at 0 to 7 days after irrigation in control, whereas it ranged from 1.56 to 1.6 and 1.55 to $1.5 \mathrm{~mm} \mathrm{~min}^{-1}$ at 0 to 7 days after irrigation in $16 \mathrm{t} \mathrm{FYM} \mathrm{ha}^{-1}$ and $13 \mathrm{t} \mathrm{PM} \mathrm{ha}^{-1}$ treatments, respectively (Figure 2A). OM increased the WHC which ranged from 0.8 to $0.3 \mathrm{~g} \mathrm{~g}^{-1}$ at 0 to 7 days after irrigation in control compared to a range of 0.82 to 0.8 and 0.8 to $0.71 \mathrm{~g} / \mathrm{g}$ at 0 to 7 days after irrigation in $16 \mathrm{t} \mathrm{FYM} \mathrm{ha}^{-1}$ and $13 \mathrm{tPM} \mathrm{ha}^{-1}$ treatments, respectively (Figure 2B). Likewise, the SWC increased from the OM application, ranging from 45.8 to $46 \%$ and 45.5 to $43 \%(v / v)$ at 0 to 7 days after irrigation in $16 \mathrm{t} \mathrm{FYM} \mathrm{ha}^{-1}$ and $13 \mathrm{t} \mathrm{PM} \mathrm{ha}^{-1}$ treatments, respectively, whereas in control it ranged from 45 to $27 \%$ at 0 to 7 days after irrigation. The RAWC increased from OM application to a great extent (Figure 2D). RAWC ranged from 18 to $12 \%(v / v)$ at 0 to 7 days after irrigation in control, and it ranged from 18 to $17 \%$ and 18 to $13 \%$ at 0 to 7 days after irrigation under $16 \mathrm{t} \mathrm{FYM} \mathrm{ha}{ }^{-1}$ and $13 \mathrm{t} \mathrm{PM} \mathrm{ha}^{-1}$ applications, respectively. 


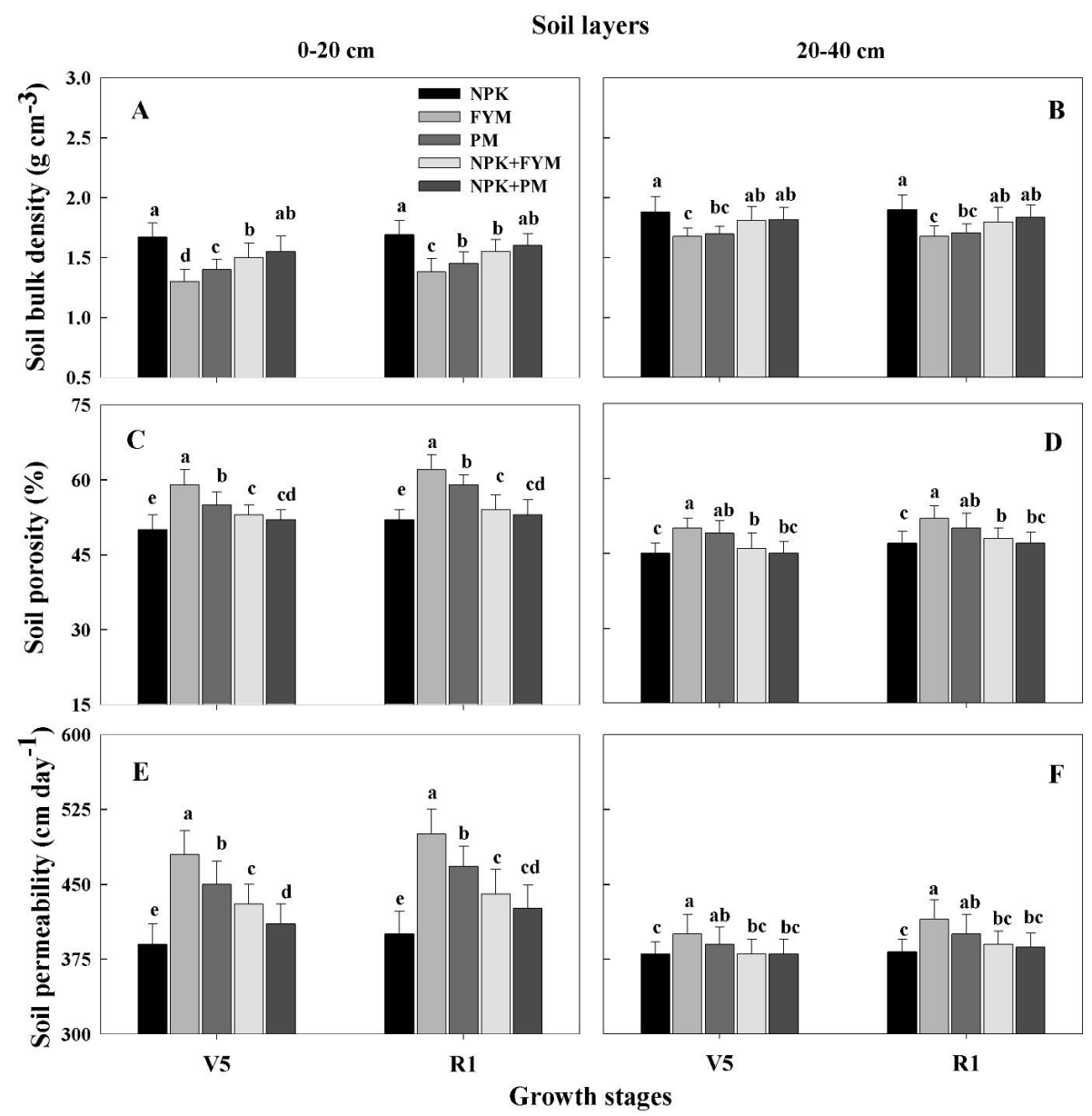

Figure 1. Effect of organic manures and inorganic fertilizers on porosity, bulk density and permeability of soil from the 0-20 cm (A,C,E) and 20-40 cm (B,D,F) soil layers at five-leaf (V5) and silking (R1) stages. Data use the mean of two years' measurements. Vertical bars above means indicate the standard error for six replications $(n=6)$ and bars followed by different lowercase letters are significantly different at $p<0.05$.

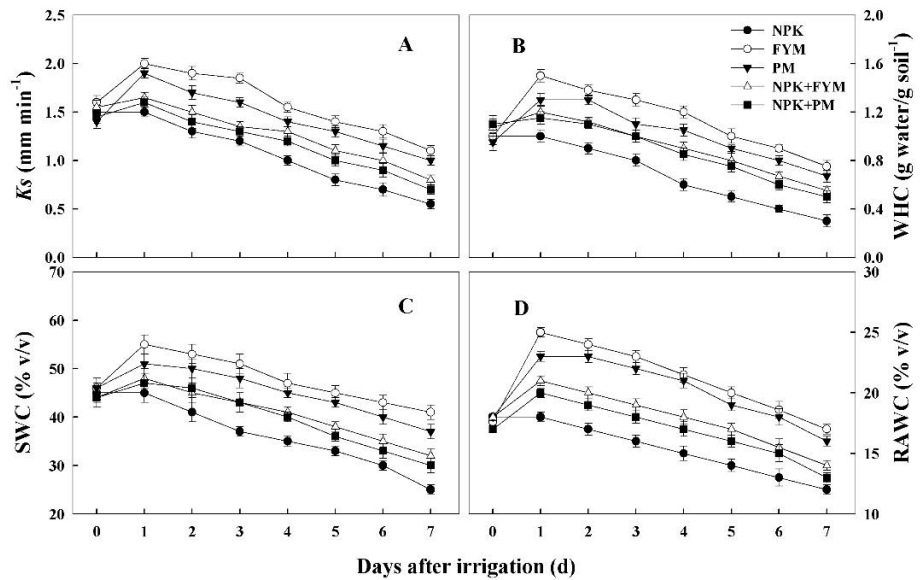

Figure 2. Effect of organic manures and inorganic fertilizers on saturated hydraulic conductivity $(K s ;(\mathbf{A}))$, water holding capacity (WHC; $(\mathbf{B}))$, saturation water content $(\mathrm{SWC} ;(\mathrm{C}))$ and readily available water content (RAWC; (D)) after applying the irrigation; 0 indicates the measurements of the plot soils one day after irrigation before the start of experiment. Vertical bars indicate the standard error of six replications $(n=6)$ at $p<0.05$. 


\subsection{Effects on Plant Root Length}

Figure 3 illustrates the progressive increase in root length of maize plants, which reached a maximum at R6. The data show that the root length of maize plants was affected by the sources of nutrients. OM sole application, as well as its integrated application with chemical NPK, increased the plant root length at all growth stage of the crop. The highest root lengths $(75 \mathrm{~cm})$ were recorded in the plots where inorganic fertilizers were applied with $7 \mathrm{tha}^{-1} \mathrm{PM}$ and $8.5 \mathrm{tha}^{-1} \mathrm{FYM}$.

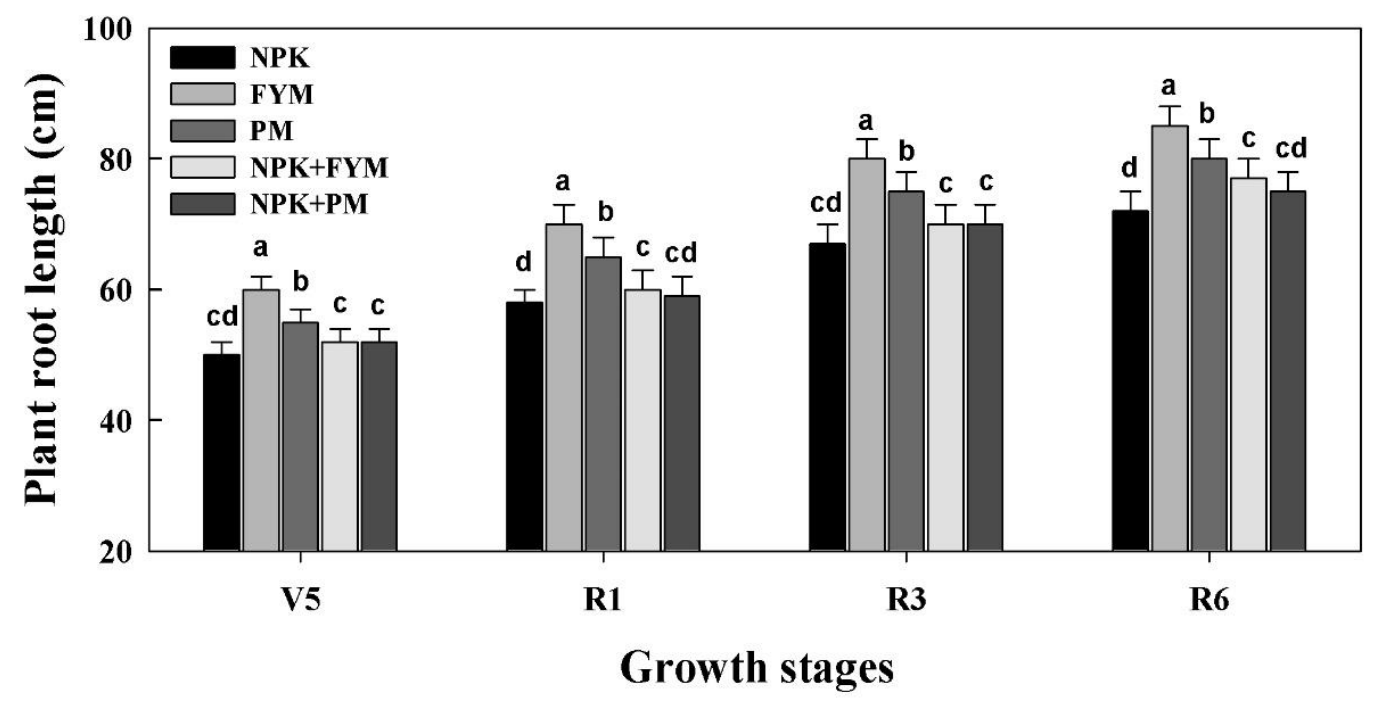

Figure 3. Effect of organic manures and inorganic fertilizers on root length of maize plant at five-leaf stage (V5), silking stage (R1), milk stage (R3) and physiological maturity stage (R6). Vertical bars above means indicate standard error for six replications $(n=6)$ and bars followed by different lowercase letters are significantly different at $p<0.05$.

\subsection{Effects on Soil Chemical Properties}

Significant differences were observed among the treatments for soil $\mathrm{pH}$, organic carbon, extractable $\mathrm{N}$ and $\mathrm{K}$ and available $\mathrm{P}$ concentrations under application of $\mathrm{OM}$ and inorganic fertilizers during the transit growth stages of the crop (Figures 4 and 5). The soil $\mathrm{pH}$ was higher at $\mathrm{V} 5$ and $\mathrm{R} 1$ and then it decreased during R3 and R6. Soil $\mathrm{pH}$ decreased with the application of OM and lower values were recorded under the OM application treatments, either alone or in combination with mineral fertilizers. The concentration of the nutrients in the soil was higher during the V5 and R1 stages and then a decrease was observed. It was observed that the plots treated with OM showed higher levels of organic carbon content. Maximum organic carbon was recorded under the treatment amended with $16 \mathrm{tha}^{-1} \mathrm{FYM}$ and $13 \mathrm{t} \mathrm{ha}^{-1} \mathrm{PM}$ applications. At $\mathrm{V} 5$ and $\mathrm{R} 1$, higher extractable $\mathrm{N}$ was recorded in the treatments using mineral NPK applications both in sole application and integrated application with OM, whereas, at the subsequent stages (R3 and R6), higher $\mathrm{N}$ content was recorded in the plots treated with sole applications of OM. Similarly, maximum available $\mathrm{P}$ and extractable K contents were observed under sole application of mineral NPK during V5 and R1 and then a decrease occurred in K and $\mathrm{P}$ during the subsequent stage. An opposite trend was recorded under the treatments using sole OM application or in combination with mineral NPK. 


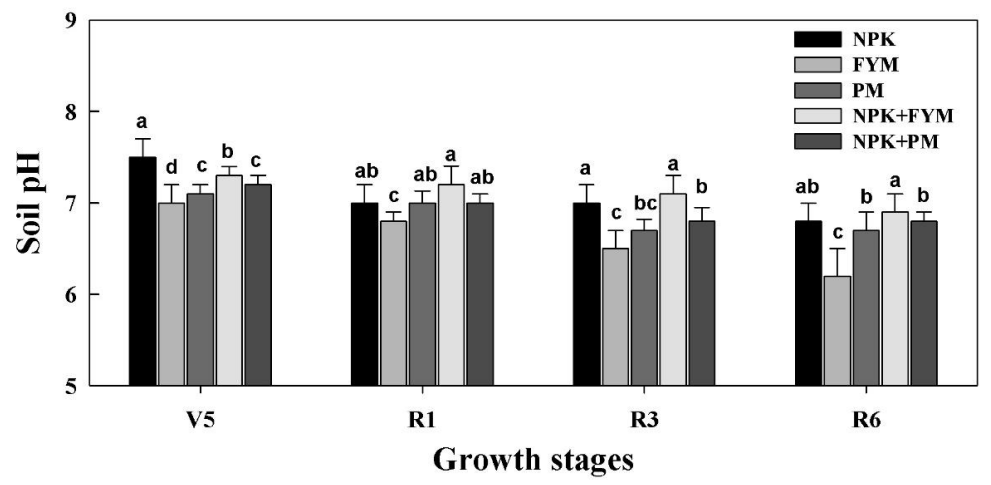

Figure 4. Effect of organic manures and inorganic fertilizers on soil $\mathrm{pH}$ at five-leaf stage (V5), silking stage (R1), milk stage (R3) and physiological maturity (R6). Vertical bars above means indicate standard error for ten replications $(n=10)$ and bars followed by different lowercase letters are significantly different at $p<0.05$.

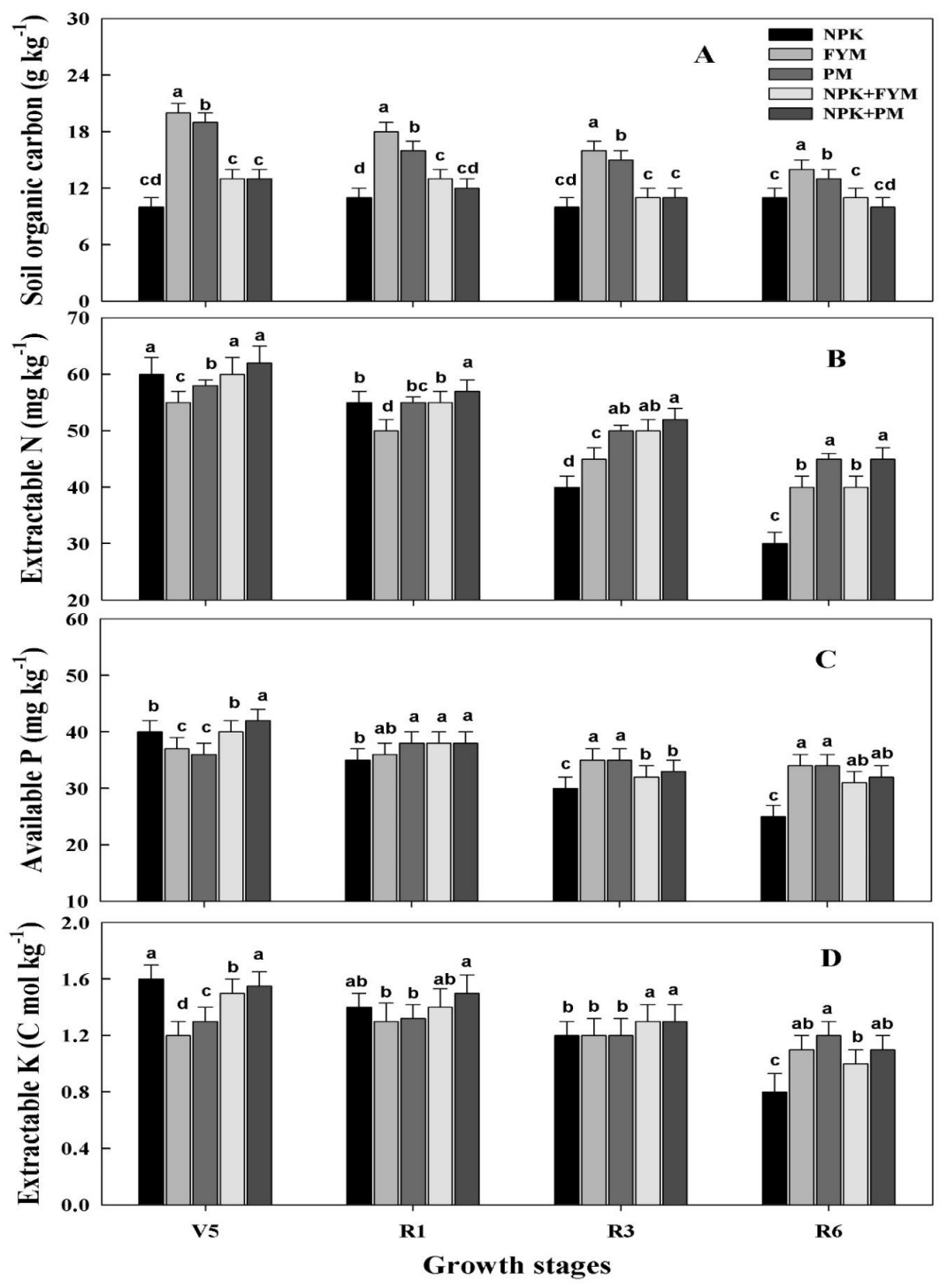

Figure 5. Effect of organic manures and inorganic fertilizers on contents of soil organic carbon (A), extractable N (B), available P (C) and extractable K (D) at five-leaf stage (V5), silking stage (R1), milk stage (R3) and physiological maturity (R6). The values are the means of at least three replications $(n=3)$ at $p<0.05$. 


\section{Discussion}

Crop production is a soil-based process that involves extracting nutrients from the soil and supplying staple foods for humanity. Effective and efficient approaches to slowing down and reversing nutrient depletion will be required in order to maintain and increase long-term soil quality and crop productivity. The results of this study show that increasing crop yields and sustaining them at a high level must include an integrated nutrient approach along with other complementary measures.

The increase in grain yields under integrated application of nutrient sources (Table 3) might have been due to the availability of nutrients throughout the growth period and the synergistic impact of OM, which could potentially have supplemented the chemical fertilizers to rapidly supply the immediately required nutrients to crop plants. Our results showing that crop productivity increased through application of inorganic fertilizers in integration with $\mathrm{OM}$ are in accordance with the findings of studies on different crops. The positive effect of OM addition on crop yield and soil productivity could be attributed to the improved physio-biochemical soil characteristics, favorable soil nutrient levels and greater soil water availability. Fasihi and Malik (1989) suggested in a 20-year study on sugarcane that to obtain the best potential yields, $50 \%$ of total $\mathrm{N}$ requirements should be made available in the form of FYM and 50\% in the form of inorganic fertilizers [30].

The efficiency of inorganic fertilizers was improved when used in combination with OM and this might be attributed to the improvement of soil health including better soil nutrient levels through the application of OM [4]. Tayebeh Abedi et al. (2010) found that OM application in wheat improved the soil properties and use efficiency of the recommended $\mathrm{N}$ fertilizer, and suggested that $30 \%$ of the total required $\mathrm{N}$ fertilizer for wheat production could be replaced by OM application [14]. Thus, OM enhances the efficiency of chemical fertilizers and may reduce their use and thereby crop production cost. Greater HI values obtained from the integrated nutrient treatments reflect a greater partitioning of plant dry matter from the grains than the vegetative plant tissues. Similarly, greater yield sustainability values for integrated nutrient treatments than control and separate applications of nutrient sources indicate that crop yields were more sustainable under integrated nutrient application (Table 3).

The treatments without or with low OM application showed lower soil organic carbon and available $\mathrm{N}$ levels during both growing years, which might be the outcome of the suppressed rate of mineralization resulting from less activity of soil microbes compared to the treatments with the optimum amount of OM (Figure 5). The same results were reported by Smith et al. (1993) who found that addition of organic residues can increase microbial pool sizes and their activity, $\mathrm{C}$ and $\mathrm{N}$ mineralization rates and enzyme activities related to the nutrient cycling process. Soil nutrient status showed a better response to chemical fertilizers with OM than non-OM applied treatments [31]. These results confirm the fact that $\mathrm{OM}$ application reduces the leaching of applied inorganic $\mathrm{N}$ fertilizer and promotes better use of applied nutrients [32]. A decrease in soil $\mathrm{pH}$ observed under OM application (Figure 4) might be due to the presence of humic and fulvic acids in OM, which have been reported to reduce the $\mathrm{pH}$ level of alkaline soils [33].

Greater root lengths observed in plants under OM and their integrated application treatments might reflect the long-term effect of OM on soil structure improvement by increasing the soil pore spaces and decreasing the soil compaction. Long-term cultivation without application of $\mathrm{OM}$ tends to increase soil compaction and decrease permeability and soil organic matter contents [19]. In addition, the favorable root development environment induced by the addition of OM caused more and longer maize plant roots over the growth period of the maize, which could absorb more moisture over longer periods from the root zone to supply greater amounts of water to the crop. That organic manuring enhances the root development is also in line with the results of Bilalis et al. (2012) who recorded greater root lengths and above-ground dry biomass in plots treated with green manure [34].

Long-term and non-sustainable agricultural practice has resulted in poor soil qualities such as degradation, fertility exhaustion, erosion and compaction $[3,19,35]$. The addition of organic amendments in this study demonstrated a significant improvement in the soil physical properties associated with the structural stability of the soil (Figure 3). These results are also in accordance with 
previous findings that soil aggregation and porosity are essentially improved by the presence of soil organic matter and microbiological activity $[4,32,36]$. The lower soil bulk density resulting from $\mathrm{OM}$ addition may decrease the degree of soil compaction, while improved soil porosity could enhance the aeration and moisture preservation capacity. Readily available water is the content of water that a plant can uptake from the soil while available water is the amount of water retained in the field between water holding capacity and the permanent wilting point of the soil. We determined the effect of OM application on water retention properties during the silking stage because the period between silking and maturity is the crucial period for kernel formation and maize requires enough water to maintain its reproductive growth. The incorporation of OM improved both the soil readily available water contents and saturation water contents after irrigation, both of which were available to plants. The increased water availability might be related to the increased micro- and macro-porosity of soil. Hathaway-Jenkins et al. (2011) reported that the soil permeability rate was about three times higher in organically managed grassland soils than conventionally managed soils [20]. In addition, they noted that organically managed soils reduced the predicted runoff by up to $28 \%$ by increasing the soil saturation and permeability rates. Similarly, Gangwar et al. (2006) concluded that integrated application of FYM with chemical fertilizers resulted in 44\% more organic matter in the soil, $25 \%$ higher porosity and 16 times more water holding capacity than the sole application of chemical fertilizers [12]. From the results of our study, it can also be suggested that soil bulk density, porosity, soil structure and soil-water properties are not constant and can be altered positively through nutrient management.

All types of OM significantly increased the water holding capacity of soil, suggesting that this is the best option for retaining more water in soil and thus saving time, money and energy in the cost of frequently irrigating the crops. Additionally, the increased water retention due to OM application may contribute to overcoming the problem of uncertain water limitations under field conditions. Charles (2012) concluded that for every one percent of organic matter content, soil can hold 16,500 gallons of plant-available water per acre of soil, which roughly equals 1.5 quarts of water per cubic foot of soil for each percent of OM [37,38]. From all these soil-based positive aspects of OM and their synergistic effects with inorganic fertilizers, a practical recommendation for a maize-based cropping system would be to combine chemical fertilizers with 7-9 $\mathrm{tha}^{-1}$ FYM or PM.

\section{Conclusions}

From the results of this study, it can be concluded that integrated use of organic manures can ensure an ecologically sound technology for improving physiochemical and hydrological properties of soil and crop productivity. Therefore, either type of organic manure can be applied by farmers to minimize the risks of soil degradation and fertility depletion to gain higher crop productivity and agricultural sustainability. With added organic manures, the soil bulk density decreased and the porosity increased. Organic manures improved the water retention capacity of the soil (i.e., increased soil permeability, saturation and total available and readily available water contents). The successively higher water contents after irrigation application in the soils amended with organic manures also indicated that organic matter could hold and sustain more soil moisture levels under natural conditions. Eventually, the application of organic matter improved the plant root development, final grain yields and chemical fertilizer use efficiency in the maize-based cropping system. The higher levels of soil nutrients and the physical properties observed during the late crop growth period under organic manures application suggest that the benefits of organic manures application could be long term. However, long-term residual impacts of slowly and rapidly decomposing organic amendments may differ significantly over time. Moreover, it is likely that the effects of organic manures may differ in different soil types depending on the soil moisture status and the plant available water contents under different precipitation frequencies and intensities. Therefore, further research efforts are required to explore the residual effects of organic manures as well as their effects on soil moisture status and plant available water contents under different levels of water application. 
Author Contributions: Conceptualization, M.A., T.B., S.A., M.R., A.A.A. and M.N.A.; Data curation, M.A., T.B. and G.S.; Formal analysis, M.A., T.B. and G.S.; Funding acquisition, A.A.A. and M.N.A.; Investigation, M.A., G.S. and M.J.S.; Methodology, M.A., T.B., G.S. and R.B.; Project administration, G.S. and R.B.; Resources, G.S., S.A., A.A.A. and M.N.A.; Software, T.B., S.A., R.B., M.J.S., M.R. and A.A.A.; Supervision, R.B.; Validation, M.J.S.; Visualization, M.J.S.; Writing—original draft, M.A., S.A., M.J.S., M.R. and A.A.A.; Writing—review \& editing, S.A. and M.N.A. All authors have read and agreed to the published version of the manuscript.

Funding: The authors highly acknowledge the Higher Education Commission Islamabad, Pakistan for its support. The authors would like to extend their sincere appreciation to the Researchers Supporting Project Number (RSP-2020/180), King Saud University, Riyadh, Saudi Arabia.

Acknowledgments: The authors highly acknowledge the Government College University, Faisalabad, Pakistan for its support. The authors would like to extend their sincere appreciation to the Researchers Supporting Project Number (RSP-2020/180), King Saud University, Riyadh, Saudi Arabia.

Conflicts of Interest: The authors declare no conflict of interest.

\section{References}

1. Merino, C.; Godoy, R.; Matus, F. Soil enzymes and biological activity at different levels of organic matter stability. J. Soil Sci. Plant Nutr. 2016, 16, 14-30.

2. Rakotoson, T.; Rabeharisoa, L.; Smolders, E. Effects of soil flooding and organic matter addition on plant accessible phosphorus in a tropical paddy soil: An isotope dilution study. J. Plant Nutr. Soil Sci. 2016, 179, 765-774. [CrossRef]

3. Egodawatta, W.; Sangakkara, U.; Stamp, P. Impact of green manure and mineral fertilizer inputs on soil organic matter and crop productivity in a sloping landscape of Sri Lanka. Field Crops Res. 2012, 129, 21-27. [CrossRef]

4. Asai, H.; Samson, B.K.; Stephan, H.M.; Songyikhangsuthor, K.; Homma, K.; Kiyono, Y.; Inoue, Y.; Shiraiwa, T.; Horie, T. Biochar amendment techniques for upland rice production in Northern Laos: 1. Soil physical properties, leaf SPAD and grain yield. Field Crops Res. 2009, 111, 81-84. [CrossRef]

5. Ata-Ul-Karim, S.T.; Liu, X.; Lu, Z.; Yuan, Z.; Zhu, Y.; Cao, W. In-season estimation of rice grain yield using critical nitrogen dilution curve. Field Crops Res. 2016, 195, 1-8. [CrossRef]

6. Nayak, A.; Gangwar, B.; Shukla, A.K.; Mazumdar, S.P.; Kumar, A.; Raja, R.; Kumar, A.; Kumar, V.; Rai, P.; Mohan, U. Long-term effect of different integrated nutrient management on soil organic carbon and its fractions and sustainability of rice-wheat system in Indo Gangetic Plains of India. Field Crops Res. 2012, 127, 129-139. [CrossRef]

7. Abid, M.; Tian, Z.; Ata-Ul-Karim, S.T.; Cui, Y.; Liu, Y.; Zahoor, R.; Jiang, D.; Dai, T. Nitrogen nutrition improves the potential of wheat (Triticum aestivum $\mathrm{L}$.) to alleviate the effects of drought stress during vegetative growth periods. Front. Plant Sci. 2016, 7, 981. [CrossRef]

8. Güereña, D.T.; Kimetu, J.; Riha, S.; Neufeldt, H.; Lehmann, J. Maize productivity dynamics in response to mineral nutrient additions and legacy organic soil inputs of contrasting quality. Field Crops Res. 2016, 188, 113-120. [CrossRef]

9. Hepperly, P.; Lotter, D.; Ulsh, C.Z.; Seidel, R.; Reider, C. Compost, manure and synthetic fertilizer influences crop yields, soil properties, nitrate leaching and crop nutrient content. Compost Sci. Util. 2009, 17, 117-126. [CrossRef]

10. Arif, M.; Ali, K.; Jan, M.T.; Shah, Z.; Jones, D.L.; Quilliam, R.S. Integration of biochar with animal manure and nitrogen for improving maize yields and soil properties in calcareous semi-arid agroecosystems. Field Crops Res. 2016, 195, 28-35. [CrossRef]

11. Ram, N. Effect of continuous fertilizer use on soil fertility and productivity of a Mollisol. In Long-Term Soil Fertility Management through Integrated Plant Nutrient Supply: Proceedings of a National Workshop Held during 2-4 April, 1998 at Indian Institute of Soil Science, Bhopal; All India Coordinated Research Project on Long-Term Fertilizer Experiments: Bhopal, India, 1998; pp. 229-237.

12. Gangwar, K.; Singh, K.; Sharma, S.; Tomar, O. Alternative tillage and crop residue management in wheat after rice in sandy loam soils of Indo-Gangetic plains. Soil and Tillage Res. 2006, 88, 242-252. [CrossRef]

13. Jones, D.L.; Healey, J.R. Organic amendments for remediation: Putting waste to good use. Elements 2010, 6, 369-374. [CrossRef]

14. Abedi, T.; Alemzadeh, A.; Kazemeini, S.A. Effect of organic and inorganic fertilizers on grain yield and protein banding pattern of wheat. Aust. J. Crop Sci. 2010, 4, 384. 
15. Garcia-Gil, J.; Plaza, C.; Soler-Rovira, P.; Polo, A. Long-term effects of municipal solid waste compost application on soil enzyme activities and microbial biomass. Soil Biol. Biochem. 2000, 32, 1907-1913. [CrossRef]

16. Yamato, M.; Okimori, Y.; Wibowo, I.F.; Anshori, S.; Ogawa, M. Effects of the application of charred bark of Acacia mangium on the yield of maize, cowpea and peanut, and soil chemical properties in South Sumatra, Indonesia. Soil Sci. Plant Nutr. 2006, 52, 489-495. [CrossRef]

17. Gruhn, P.; Goletti, F.; Yudelman, M. Integrated Nutrient Management, Soil Fertility, and Sustainable Agriculture: Current Issues and Future Challenges; International Food Policy Research Institute: Washington, DC, USA, 2000.

18. Bodruzzaman, M.; Meisner, C.; Sadat, M.; Hossain, M.I. In Long-term effects of applied organic manures and inorganic fertilizers on yield and soil fertility in a wheat-rice cropping pattern. In Proceedings of the 19th World Congress of Soil Science, Brisbane, Australia, 1-6 August 2010; pp. 10-15.

19. Brady, N.C.; Weil, R.R. Elements of the Nature and Properties of Soils; Pearson College Div: New York, NY, USA, 2004.

20. Hathaway-Jenkins, L.; Sakrabani, R.; Pearce, B.; Whitmore, A.; Godwin, R. A comparison of soil and water properties in organic and conventional farming systems in England. Soil Use Manag. 2011, 27, 133-142. [CrossRef]

21. Shiferaw, B.; Smale, M.; Braun, H.-J.; Duveiller, E.; Reynolds, M.; Muricho, G. Crops that feed the world 10. Past successes and future challenges to the role played by wheat in global food security. Food Secur. 2013, 5, 291-317. [CrossRef]

22. Ashworth, J.; Keyes, D.; Kirk, R.; Lessard, R. Standard procedure in the hydrometer method for particle size analysis. Commun. Soil Sci. Plant Anal. 2001, 32, 633-642. [CrossRef]

23. Haghverdi, A.; Öztürk, H.S.; Durner, W. Measurement and estimation of the soil water retention curve using the evaporation method and the pseudo continuous pedotransfer function. J. Hydrol. 2018, 563, 251-259. [CrossRef]

24. Amoozegar, A. A compact constant-head permeameter for measuring saturated hydraulic conductivity of the vadose zone. Soil Sci. Soc. Am. J. 1989, 53, 1356-1361. [CrossRef]

25. Hodnett, M.; Tomasella, J. Marked differences between van Genuchten soil water-retention parameters for temperate and tropical soils: A new water-retention pedo-transfer functions developed for tropical soils. Geoderma 2002, 108, 155-180. [CrossRef]

26. Walkley, A. A critical examination of a rapid method for determining organic carbon in soils-Effect of variations in digestion conditions and of inorganic soil constituents. Soil Sci. 1947, 63, 251-264. [CrossRef]

27. Sparks, D.L.; Page, A.; Helmke, P.; Loeppert, R.H. (Eds.) Methods of Soil Analysis, Part 3: Chemical Methods; John Wiley \& Sons: Hoboken, NJ, USA, 2020; Volume 14.

28. Bray, R.H.; Kurtz, L. Determination of total, organic, and available forms of phosphorus in soils. Soil Sci. 1945, 59, 39-46. [CrossRef]

29. Rhoades, J. Salinity: Electrical conductivity and total dissolved solids. In Methods of Soil Analysis: Part 3 Chemical Methods; Soil Science Society of America: Madison, WI, USA; American Society of Agronomy: Madison, WI, USA; Crop Science Society of America: Madison, WI, USA, 1996; Volume 5, pp. 417-435.

30. Fasihi, S.; Malik, K. Fifty Years of Sugarcane Research (1935-85) at Sugarcane Research Institute Faisalabad; Directorate of Agriculture Information of the Government of Punjab: Lahore, Pakistan, 1989.

31. Smith, L.; Papendick, R. Soil organic matter dynamics and crop residue management. In Soil Microbial Ecology. Applications in Agricultural and Environmental Management; Metting, F.B., Jr., Ed.; Marcel Dekker: New York, NY, USA, 1993; pp. 65-94.

32. Berihun, T.; Tadele, M.; Kebede, F. The application of biochar on soil acidity and other physico-chemical properties of soils in southern Ethiopia. J. Plant Nutr. Soil Sci. 2017, 180, 381-388. [CrossRef]

33. Yaduvanshi, N.; Sharma, D. Tillage and residual organic manures/chemical amendment effects on soil organic matter and yield of wheat under sodic water irrigation. Soil Tillage Res. 2008, 98, 11-16. [CrossRef]

34. Bilalis, D.; Karkanis, A.; Sidiras, N.; Travlos, L.; Efthimiadou, A.; Thomopoulos, P.; Kakabouki, I. Maize and legumes root growth and yield as influenced by organic fertilization, under mediterranean environmental conditions. Rom. Agric. Res. 2012, 211-217.

35. Brady, N.C.; Weil, R.R. Elements of the Nature and Properties of Soils; Pearson Prentice Hall: Upper Saddle River, NJ, USA, 2010. 
36. Moharana, P.; Sharma, B.; Biswas, D.; Dwivedi, B.; Singh, R. Long-term effect of nutrient management on soil fertility and soil organic carbon pools under a 6-year-old pearl millet-wheat cropping system in an Inceptisol of subtropical India. Field Crops Res. 2012, 136, 32-41. [CrossRef]

37. Gould, C.M. Compost Increases Water Holding Capacity of Droughty Soils; Michigan State University: East Lansing, MI, USA, 2015.

38. Abd El-Mageed, T.A.; El-Sherif, A.M.; Abd El-Mageed, S.A.; Abdou, N.M. A novel compost alleviate drought stress for sugar beet production grown in Cd-contaminated saline soil. Agric. Water Manag. 2019, 226, 105831. [CrossRef]

Publisher's Note: MDPI stays neutral with regard to jurisdictional claims in published maps and institutional affiliations.

(C) 2020 by the authors. Licensee MDPI, Basel, Switzerland. This article is an open access article distributed under the terms and conditions of the Creative Commons Attribution (CC BY) license (http://creativecommons.org/licenses/by/4.0/). 